\title{
CORRECTION
}

\section{Correction to: Nonlinear modeling analysis of the coupled mechanical strength and stiffness enhancement of composite materials of a Horizontal Axis Wind Turbine Blade (HAWTB)}

\author{
Omar Rajad ${ }^{1} \cdot$ Hamid Mounir ${ }^{1} \cdot$ Abdellatif El Marjani $^{1}$ • Saïf ed-Dîn Fertahi ${ }^{2}$
}

Published online: 1 March 2022

(c) Springer-Verlag France SAS, part of Springer Nature 2022

\section{Correction to: \\ International Journal on Interactive Design and Manufacturing (IJIDeM) \\ https://doi.org/10.1007/s12008-021-00790-0}

Unfortunately, abstract and keywords were incorrectly published in the original publication. The corrected version updated now.
The original article has been corrected.

Publisher's Note Springer Nature remains neutral with regard to jurisdictional claims in published maps and institutional affiliations.

The original article can be found online at https://doi.org/10.1007/ s12008-021-00790-0.

Omar Rajad

rajadomar@gmail.com

1 EMISys Research Team, Engineering 3S Research Center, Mohammadia School of Engineers, Mohammed V University in Rabat, Avenue Ibn Sina, Agdal, BP 765, Rabat, Morocco

2 Thermodynamics and Energy Research team, Energy Research Center, Physics Department, Faculty of Science, Mohammed V University in Rabat, 4 Avenue Ibn Batouta, B.P 1014, Rabat, Morocco 